\title{
TOMAS FAIST
}

\section{THE MIGRATION-SECURITY NEXUS. INTERNATIONAL MIGRATION AND SECURITY BEFORE AND AFTER 9/11}

Willy Brandt Series of Working Papers in International Migration and Ethnic Relations

4/03

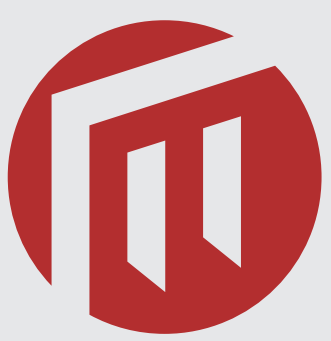




\section{Willy Brandt Series of Working Papers}

in International Migration and Ethnic Relations

4/03

Published

2004

\section{Editor}

Maja Povrzanović Frykman

maja.frykman@imer.mah.se

Editor-in-Chief

Björn Fryklund

\section{Published by}

School of International Migration and Ethnic Relations

Malmö University

20506 Malmö

Sweden 


\section{THE MIGRATION-SECURITY NEXUS. INTERNATIONAL MIGRATION AND SECURITY BEFORE AND AFTER 9/11'}

9/I I has reinforced the discursive securitization of migration and integration politics and policies in major immigration countries, the so-called migration-security nexus. To explore this argument, the analysis deals with three propositions. First, the end of the Cold War has opened political space for focusing on diffuse and hard-to-grasp security threats that do not emanate from sovereign states but from non-state actors, involving issues such as crime, drugs, migration. International migration has served as a convenient reference point for unspecific fears. Second, securitizing policies such as stepped-up border controls and stricter internal surveillance of immigrants produces unintended effects. Securitizing policy issues creates higher expectations among voters that governments are actually able to effectively control transnational movements. Third, 9/I I entails ambiguous consequences for immigrant integration. Clearly, the levels of harassment against immigrants from the Middle East increased considerably, at least on the short term. Yet the crisis situation may even lead to an increased immersion into the politics of the respective national immigration states. General attitudes and policies towards cultural pluralism will probably not be significantly affected by 9/I I . Overall, the exploration of the migration-security nexus is part of broader studies into the virtuous and vicious cycles of transnationalization, the growing importance of non-state actors in world and national politics.

Keywords: international migration, immigration, security, transnationalism 
"The ploughman shall go out in March and turn the same earth he has turned before.

By then what wrong will the black earth cover, what wrong will have been done. We wait and the time is short, but waiting is long."

T. S. Eliot

September I I reminded us that terrorism as a method to spread of mass fear is not only used by authoritarian states and dictatorships but also by non-state actors, in this case the network Al Qu'aida. Undoubtedly, what is now called 9/I I came as a shock to all of us although it was not the first instance of spectacular non-state violence and terrorism. Yet it was a unique case of wanton destruction directed at a national and global nerve center. It is different from acts grounded in organizations with clear political goals such as ethno-nationalist movements which are usually labeled terrorist by the governments of countries affected - for example, the Basque ETA in Spain or the Irish Republican Army (IRA) in Northern Ireland. 9/I I certainly has global ramifications which transcend the regional or national character of the organizations just mentioned. Yet while 9/I I may mark a turning point in the history of non-state terrorism, it is part of the politics of terrorism and reflects the changing trench lines and clashes in world politics, in this case the world after the Cold War. To classify the phenomenon is fraught with difficulties, not least because the term terrorism is itself part of a semantic war. For example, during the Cold War the USA spoke of Moscow as the source of terrorism, and in the post Cold War disorder since 200I the networks of $A l$ Qu'aida around Osama bin Laden have become the center of attention. Increasingly, fears of communist takeover and infiltration have been replaced in popular and mass media coverage by more diffuse perceptions of transnational threats associated with organized crime, drug trafficking and environmental disasters - and not to forget international migration.

These policy areas have been characterized by securitization. This refers to the overall process of turning a policy issue such as drug trafficking or international migration into a security issue. The term securitization refers to a perception of an existent threat to the ability of a nationally bound society to maintain and reproduce itself. Securitization has emerged in a new academic literature in the field of international relations $\&$ international politics, which even before 9/I I, has begun to highlight more fundamental concerns about "new" security issues. Such new security issues comprise very different phenomena ranging from international terrorism, ethno-national strife to environmental degradation, food and energy scarcities, drug trafficking, population growth, illegal viz. unauthorized migration, and organized crime - to mention only the most prominent ones. Most noteworthy, not all of these issues are necessarily state-cen- 
tered, as in the old paradigm about "national security" (Buzan et al. I998). It is thus not surprising that the post-Cold War period has seen efforts to view international migration as an important regional and geo-strategic dynamic with potentially crucial effects upon states, societies and their security (Weiner I995). The migration-security analysis extends the nave-gazing view at the OECD world with a more comprehensive analysis including both the developed and developing world.

After 9/I I, it is worth noting that mass-cultural fantasies about catastrophes caused by terrorists have been around for several decades. Even academic publications, such as Jessica Stern's The Ultimate Terrorists - published two years before 9/I I (Stern I999), start with the scenario of an atomic bomb devastating Manhattan. Quite often, dire and populist scenarios have been connected also to international migration, alluding to the proverbial "other" and "stranger" as a source of threat to "our" jobs, housing and borders, but also more far-reaching ontological threats to the borders of sovereign states, bodily security, moral values, collective identities and cultural homogeneity. Examples include not only reports in manifold organs of the popular press but also academic worst-case scenarios in fields such as demography (e.g. Birg 200I) and political studies (e.g. Kurth I994). This connection between international migration, on the one hand, and human and state security, on the other hand, is called here the migration-security nexus.

In such a complex setup, the question cannot simply be how international population movements contribute to create conflicts within and between states. Instead, it is also important to ask why migration has increasingly become a matter of security. Why has the migration-security nexus developed? In other words, why have quite a few citizens in the West have taken recourse to sometimes fantastic threats posed by international migrants even before 9/II? And what are the consequences for immigration and immigrant integration? There is ample evidence to look at the consequences. After all, at least in the discursive realm, the responses to the events on 9/I I by politicians and journalists have reinforced the migration-security nexus, dramatizing a publicly convenient link between international migration and security. Governments all over Western Europe and North America have not only strengthened border viz. external controls but also internal controls of non-citizen immigrants. In the country obviously most affected by $9 / \mathrm{II}$, the USA, institutional responses have been the most far-reaching. For example, the new U.S. Department of Homeland Security (DHS), which formally opened for business in early 2003 , consolidated some I70,000 government personnel from 22 agencies - including the Immigration and Naturalization Service (INS). It is the largest modification of the U.S. federal bureaucracy since the founding of the Pentagon more than 50 years ago 
during World War Two, and suggests that security threats are now increasingly seen also as internal ones. In Germany, to give another example for the repercussions of $9 / \mathrm{I}$ I, the reactions first delayed the passage of the new immigration law because governing and opposition parties could not agree on tighter checks upon applicants for citizenship. Eventually, the fallout of 9/I I, among other factors, played a role for the law to be delayed indefinitely. These two examples suggest that there is much to be gained from a more systematic analysis of the consequences of $9 /$ I I for the unfolding migration-security nexus.

Towards this end I wish to posit three propositions:

\section{Proposition I: Context of the Migration-Security Nexus}

The end of the Cold War has widened the political space for actors in the public sphere to focus on diffuse and hard-to-grasp security threats that do not emanate from sovereign states but from non-state actors, involving issues such as crime, drugs, migration. International migration has served as a convenient reference point for unspecific fears. The depiction of international migration as a security threat in the West has unwillingly contributed to what the American political scientist Samuel Huntington has termed the "clash of civilizations" (Huntington 1995). Securitizing migration reinforces the very stereotypes about cultural fears and clashes that politicians publicly deny and abstain.

\section{Proposition 2: Unintended Consequences of Securitizing Migration}

Securitizing policies such as stepped-up border controls and stricter internal surveillance of immigrants produces manifold unintended effects. Among others, securitizing policy issues creates higher expectations among voters that governments are actually able to effectively control transnational movements. This is in stark contrast to the past few decades, where measures such as border control could be viewed and interpreted as largely symbolic measures. In turn, the rising expectations generated by increased external and internal controls among the populace may lead governments to continue presenting transnational movements as grave security risks. In the end, this may create incentives for political actors to engage in symbolic meta-politics.

\section{Proposition 3: Consequences for Immigrant Integration}

9/I I entails ambiguous consequences for immigrant integration. Clearly, the levels of harassment against immigrants from the Middle East increased considerably, at least on the short term. Yet the crisis situation has also sparked internal debates within Muslim immigrant groups and organizations about the mode of accommodation to the societies of settlement. This may even lead to an increased immersion into the politics of the respective national immigration states. 
General attitudes and the broad outlines of policies towards cultural pluralism will probably not be significantly affected by $9 /$ I I .

The first part of the following analysis opens the historical window of opportunity in which international migration has turned into a security issue. Specific reference is made to the post-Cold War period. The second part briefly lists some of the consequences of securitization of international migration, namely increased meta-politics which connects social problems such unemployment and security threats to migration and immigration. The third section turns to the less than clear-cut implications of 9/I I for the incorporation of new immigrant groups, in particular the category Muslims. The discussion closes with perspectives for research on the role of non-state, transnational actors in national and world politics.

\section{The Historical-Structural Background - Furthering the Linkage of Migration and Security}

In recent times, migration as a security threat has emerged with end of the Cold War. Transnational diasporas, in particular, such as some Islamic groups are seen by some observers to have taken recourse to violent means in order to escape a cul-de-sac in what they perceive as Western values, political orders and styles of life (cf. Lewis 2003). While politics has often connected international migration to security issues over the past I 50 years, the end of the Cold War has been the most recent stimulus which favored the spread of objectless fear. This historical threshold not only meant the disappearance of a powerful external threat to security of the West but also the loss of an important source of cohesion between the diverse groups which constitute the Western world. This transformation and the fall of some authoritarian regimes opened up a space for marginalized identities in Eastern Europe, Central and even Southeast Asia to more freely and sometimes quite aggressively assert suppressed national and ethnic identities. In this changing inter- and transnational context, even sovereign states have begun to view security as the collective management of sub- or transnational threats and the policing of borders and the internal realm, rather than just the defense of territory against external attack.

In Europe, the perceived resurgence of Islam as a political force in increasingly multiethnic societies has been often discussed in connection with Muslim immigrants as such, but above all with regard to diasporas. Relations between countries such as France and Algeria or Germany and Turkey have been fraught by the export and import of conflicts surrounding politicized forms of Islam and national liberation. Apart from substantial human security and state security issues involved in border-crossing authoritarian social movements such as 
the Kurdish PKK, diasporas have become the quintessential expression of globalization associated with the movement of people across borders - as distinct from the flow of goods, capital and services (on diasporas and security, see Sheffer I993 and Davies 2000). Such transnational communities are by no means confined to Muslim communities. One specific form of transnational community - diaspora - denotes ethno-national and/or religious groups who have settled in a country different from the country of origin, who have remained or turned into minority groups, are frequently resisting assimilation, and strive for return to an (imagined) homeland, often after the experience of forced dispersal (Faist 2000a: chapter 7). This description includes the archetypal Jewish experience, followed by Armenians and Palestinians. In other situations, transnational communities comprise political dissidents, such as some Cubans in the USA, former indentured labor, such as Chinese or middlemen minorities such as Indians all over the world. Reference to such groups has been ideal for setting disloyalty on the public agenda in debates over dual citizenship, and lacking accountability viz. legitimacy in conflicts over national unity. Public debates also include the allegations of the extraordinary influence of small lobbies on foreign policies. Notably the Jewish, Greek and Armenian diasporas in the USA are thought to profoundly affect foreign policy on behalf of their homeland through means such as military and economic assistance, arms sales, media pressure, petitions, and electoral campaign threats (cf. Shain I989).

Public and academic attention has thus focused almost exclusively on the negative consequences of transnational organizations and communities for the countries of settlement. This is surprising at first sight because such bordercrossing groups can also be thought and may indeed have - under propitious circumstances - positive effects as conduits for the rule of law and the spread of civil and human rights (Keck \& Sikkink 1998). Nowadays, the conditions for an effective mix of territorial exit and political voice (cf. Hirschman I970) have increased because most emigration countries do not resemble the strong authoritarian states of the early and mid- $20^{\text {th }}$ century. Transnational activists thus encounter somewhat more propitious conditions to reinforce political transitions towards rule of law in their home countries.

And even if we doubted the utopian visions of transnational actors as conduits for human rights and democracy, there is clear evidence not only for the import of conflicts in the wake of migration but also for effects moderating transnational conflicts. For example, Algerian communities and organizations in France, on the whole, have probably had a moderating effect on the situation in Algeria since 1992 (Miller 2000): In that year the Islamic Salvation Front was barred from attaining power and a civil-war like situation has ensued, which has been going on until today. Also, a balanced appraisal of immigration and 
security cannot overlook that sometimes immigrants themselves are those interested in dismantling terrorist groups. For example, it was Arab-background immigrants who helped French police to dismantle the Armed Islamic Group in 1995. Such evidence comes from Turkish immigrants in Germany and their role in tackling extortion practices by the Kurdish PKK (cf. Faist 200ob). It is worth noting that substantial conflicts in countries of origin such as Algeria and Turkey have at times spilled over since the I970s but did at no time significantly endanger state or human security in France and Germany.

To draw up an interim balance concerning the post cold war period, the emergence of the migration-security nexus cannot be explained exclusively by actual threats to state and human security, as threats to the physical integrity of persons in immigration societies or endangering the institutional integrity of states receiving immigration. We thus need to take a closer look at the political psychological mechanisms of threat construction.

To start with, 9/I I and the dangers apparent are not simply made up. This was a murderous event. We know from research on intergroup relations, intolerance, elite decision-making, and reactions to terrorism before 9/I I that the responses by governments and publics to threats have been going mainly in one direction. The research carried out on these phenomena in various fields of the social sciences such as social psychology, political psychology and sociology arrives at remarkably similar conclusions. Diverse studies have found that external threat results in a broad tendency to heighten in-group solidarity, vilify the source of threat, limit government actions that might assist members of the threatening group, and support belligerent solutions directed at the threatening individuals or group (For many, see Coser 1956, Cottam 1994, Gibson I998; Sales \& Friend I973). It is needless to say that these reactions can be readily observed in responses to $9 / \mathrm{I}$ I.

But we need to dig deeper. 9/I I seems to have reinforced the trend towards securitizing migration and immigration - it did not create it from scratch. Immigration - not only when connected to terrorism - has usually resulted in an increase in perceived threats. Even in less dramatic instances not connected to terrorism but to material threats and the import of conflicts from countries of origin into countries of settlement of immigrants, the security narrative demands that fear and objectless fear - Angst - have to be controlled. In the end, the migration-security nexus under the circumstances before 9/I I also dealt with cultural values affected that are linked to ontological security, and thus existential threats. As immigration history shows, foreigners or immigrants were frequently perceived to threaten cultural identity (cf. Zolberg 1987). Wild swings in immigration policy have not only come about by infrastructural considerations or material threats but also as a result of fears about the cultural 
fabric of societies. Examples reach from anti-Chinese legislation in North America and Australia in the late $19^{\text {th }}$ century (Saxton I97I) to alleged Muslim threats in Europe in the late $20^{\text {th }}$ century (e.g. Kepel I997).

Clearly, on the surface 9/I I suggested that international migration is inextricably linked to terrorism, not simply in the indirect ways just mentioned. 9/I I was not about international migrants posing threats to "our" jobs, incomes, housing or culture. It was a direct attack and a threat to death. However, the links between international migration and security threats are inconclusive even after 9/I I. Migration and security only superficially share the fact that border crossings are involved. Moreover, not all flows of persons across the borders of sovereign states constitute migration. Tourists and business travelers account for more border crossings than labor migrants or refugees (IOM 200I). In particular, the link between migration and increases in other phenomena, such as drug trafficking and crime, is vastly overstated. Potentially, large immigration flows may enhance the opportunities and provide low-cost means such as couriers to distribute drugs. Also, immigrant communities such as secluded religious sects could make it easier for would-be terrorists to find anonymity. And in exceptional circumstances of large immigration flows some native workers may be adversely affected by immigrants in terms of jobs and wages. But it is a long stretch from there to argue that even a partial solution to certain country's drug, crime, unemployment and physical security problems would be significantly affected by acting on immigration flows. Moreover, even stricter border controls do not constitute a suitable means to combat terrorism. Immigration and visa control policies are far less likely to catch a determined terrorist than they are to control unauthorized immigration.

Given this context, it is worth noting, however, that migration policies are often even institutionally linked to crime. This clearly goes beyond merely discursive connections. For example, the European Union (EU) created two groups in the I 980 os - the TREVI group, in which ministers of justice and interior discussed issues of police cooperation including terrorism; and the Ad hoc Group on Asylum and Immigration, where the same ministers met informally to discuss the harmonization of asylum and immigration policies. These two groups were the forerunners of the Justice and Home Affairs Council and successive institutional EU mechanisms to deal with these policy areas. Such institutional connections between terrorism, crime and migration - which are distinct from border-crossing traffic - send ambiguous signals to populist politicians and audiences. They reinforce - albeit not on the same scale as 9/I I - already existing scenarios of threat although politicians of mainstream parties take great care to escape such charges. The political uses of 9/I I have exacerbated the already existing discursive linkages of threat, migration and the clashes of cultures. 


\section{Unintended Consequences of Securitizing Migration \\ - Reinforcing Meta-Politics}

The border control initiatives of national states in Europe and North America before 9/I I were politically successful policy failures that succeeded in terms of their symbolic and image effects even while sometimes or even largely failing in terms of their deterrent effects. According to the Continuing Observation System on International Migration, the estimated number of irregular bordercrossings and irregular migrants has by no means decreased during the I990s the reverse assumption may render a truer picture (e.g. SOPEMI I99I). Since September I I internal and external control of migrants has increased. In particular, measures which try to handle the migrant as an illegal border crosser make him or her more visible as an alien. For example, due to ever-stricter border controls unauthorized viz. irregular migration gains more visibility. The very collection of statistics may legitimize stricter border controls and could further contribute to the perception of the migrant as illegitimate and potentially criminal, although politicians take great care to accuse the traffickers and depict the migrants as victims. All of this has an ironic side to it because border control is one of the few remaining fields in which major immigration states have shown that their autonomy has not been hampered by growing globalization of the flow of people.

Yet stepping up migration control visibly, governments will have to show that their increased control efforts show visible results. For example, the number of illegal border crossers apprehended may need to go up. And governments have to uphold migration as a potential security threat. Otherwise, it would be hard to justify increased resources devoted to the control of internal and external borders. This creates incentives for meta-politics; following a lead by Harold Lasswell who had coined the term "meta-issue" (cf. Faist I994): Meta-politics connects social problems and security concerns with fears around international migration. Immigration can be referred to by politicians in explaining many social, economic and security problems - such as unemployment, housing shortages, crime - without having to give concrete evidence, not the least because the effects of immigration are exceedingly hard to establish empirically with a sufficient degree of certainty. The academic and public disputes over the fiscal impact of immigration are just one prominent case in point (for an overview, see Fix \& Passel I994). In referring to these fears and in being responsive to the expectations of their constituency, especially politicians from populist parties have in fact introduced and reinforced xenophobic tendencies. This is not to say that threats to security in immigration countries are without any real-world foundation. However, through meta-politics, low-level threats usually gain out-of-proportion significance. Meta-politics also means that poli- 
tical decision-making engages in symbolic efforts instead of offering substantive policy solutions. Of course, all politics has a symbolic content. Otherwise, political actors could not aggregate and articulate interests and mobilize supporters. However, meta-politics unsettles the always-precarious balance between the material and symbolic content of politics in connecting substantive issues such as unemployment and security to symbols which signify threats in factually incorrect ways.

One implication of meta-politics is the ever-renewed juxtaposition and dualism of "us" (the Americans, the Germans, etc.) versus "them" (the immigrants, the Muslims, etc.) which is both deeply regressive and pervasive in a globalizing society. Editorials in leading newspapers around the West have pointed out that after $9 /$ I I postmodern ambiguities are out of date and have been replaced by a clear trench line between liberalism vs. terrorism. ${ }^{2}$ One may easily extend this link further to liberalism versus Islamic or Christian fundamentalism. But such simplicity overlooks the fact that wanton violence is itself aided by globalization and is also reproduced internally in those societies imbued with Western values. The massacre at Waco, Texas, is just one prominent example; the bombing in Oklahoma City another. To state the obvious: the 'Una-bomber' of Oklahoma City was not an immigrant with an Arab background but a mentally deranged former US-American physics professor.

Meta-politics may also obscure the fact that an onslaught on civil rights has taken place which not only affects non-citizens such as aliens and permanent residents viz. denizens but also citizens. Legislation passed in major western liberal democracies in the immediate aftermath of 9/I I provides ample evidence for this claim. In the USA, Congress passed a bill in October 200I which increased government's ability to supervise all residents. The UK followed swiftly and moved even further in 2003. In Germany, in December 200I, new legislation increased not only funds for the police force but also their powers of investigating and even shutting down suspicious bodies such as religious organizations which are not conforming to constitutional norms. To give one last example, French legislation passed in November $200 \mathrm{I}$ provided more means for police and security forces to invade daily life, such as a new rule connected to quiet behavior in entrance halls to large apartment buildings and the punishment of people who do not 'regularly' purchase a valid ticket for public transportation. It is needless to say that this also aims at controlling youth of immigrant background in the banlieus (cf. Césari 200I).

In general, state security institutions such as the armed forces, the police and intelligence agencies are known to deal with problems such as 9/I I in a way that enables them to use their traditional and familiar solutions (cf. Allison I97I) - in this case ranging from military attacks to increased external and in- 
ternal border controls. In this perspective, not only increased control of migrants but the whole 'war on terrorism' is a large-scale effort to cast bewildering developments such as non-state terrorism into familiar molds. After 9/I I, the state governments and the state security forces have been themselves heavily engaged in the construction of a political threat that can then be addressed by traditional means. Whether or not the threat attacked bears close resemblance with real-world phenomena is another question.

\section{Implications for Immigrant Integration - Cultural Pluralism}

In the country most obviously affected by the aftershocks of 9/I I, Muslim organizations and communities experienced a dramatic new situation (Leonard 2003): The spotlight of politics and mass media was directed towards them. The issues in public debate have focused on issues such as foreign vs. domestic rootedness of Muslim organizations, the use of violence, and gender relations. Immediately after 9/I I the U.S. Administration looked for Muslim leaders who would what the government stipulated: 'denounce fundamentalist hatemongering'. It found them, often outside the organized Muslim communities. It was not the leaders of mosques and other religious or political organizations who were the most visible spokespersons for Muslim groups after 9/I I. This is surprising because Muslim organizations have been characterized by a new wave of leadership over the past years. This new stratum does not come from spiritual leaders - for example imams - but from professional circles, such as lawyers, medical doctors or business executives. In short, most Muslim communities in the USA are nowadays run by quite secular leaders who consider good relations to mass media as a prime resource. They played only a marginal role, however, in the media hype following 9/I I. Figures marginal to Muslim communities took center stage and commanded national attention immediately after 9/I I. One prominent example is Shayk Hamza Yusuf, a white American convert with Sufi leanings. Born Mark Hanson, he converted to Islam at age I7 in the San Francisco Bay Area. Widely traveled, he has studied with Islamic scholars in Algeria, Morocco and Mauretania. He is a charismatic speaker and produces numerous, widely circulated videos and cassettes. His public appearances often generate enthusiastic audiences. Hamza Yusuf held no office in national Muslim political organizations. Yet he was one of six religious leaders and the only Muslim to meet with President George W. Bush at the White House immediately after the murderous attack on the twin towers. Shayk Hamza Yusuf also denounced all kinds of violence. He thus corresponded to the expectations of journalists and politicians, who sought out moderate Muslims, urging them to speak up, to deplore and repudiate the violent acts and those who would justify them in any way. 
We might interpret this as a specific US-American tale of dealing media-wise with 9/I I and Muslim minorities. However, the one-sided media attention on converts as spokespersons has initiated a debate within Muslim organizations not only about media visibility but also about substantial religious and political viewpoints, such as criticism of certain political regimes in the Middle East and South Asia. The hard and frequent look by American mass media on Islam and Muslims has also forced the national Muslim leadership to now speak out more openly about their positions on political accommodation and gender relations. At the same time, their rhetoric against the U.S. government subsided. To say the least, a process of intensified deliberations within Muslim organizations has been started on sensitive and contentious issues. Topics have included, for example, the hiring of local religious leaders, imams. The demand to hire only American-educated imams who are fluent in English and to train both imams and board members has been voiced more frequently in community newspapers. Also, some Muslim political organizations have tried to come up with younger and female leaders (Leonard 2003). On the short run, all this contributes to more political tensions between Muslim organizations and 'mainstream' establishment. Nonetheless, these are signs of incipient political incorporation into American public life.

To take a cursory look at a European example, German political life certainly does not offer so much leeway for marginal yet intellectual and charismatic young religious converts to Islam. This may be, by the way, partly due to the fact that there is much less of a Muslim intelligentsia in Germany compared to the US. After all, migration of the category of persons called Muslims in Germany has predominantly occurred in the context of former 'guestworker' migration, while the mass immigration patterns of Muslims to the US has been of more recent vintage, mostly since the I980s. Most important, this immigration has been socio-economically much more diverse in the US than in Europe. However, we can observe similar trends of increased public and political dialogue if not cooptation, and efforts by the political gatekeepers to include Muslim organizations at least in consultative roles. Similar to the US Administration, German government officials such as Federal President Johannes Rau have invited religious leaders. Unlike the US-American example, the German corporatist tradition has led to invite representatives of a wide range of Muslim organizations. The city of Bremen, for example, has figured prominently as a role model to be emulated by others because of its allegedly successful framework of including all varieties of Muslim, Christian and Jewish organizations and the so-called "Islam week", during which representatives from organizations ranging from the Islamist Milli Görüs to secularized Alevi communities are supposed to cooperate in order to enter into a 'dialogue' with the non-Muslim public. This 
bright Bremen public image was stained somewhat when it became known that one of the regular visitors to one of the inner-city mosques had been detained by the U.S. military at Guantanamo Bay, charged with ties to the former Taliban regime and the terrorist $A l$ Qu'aida. Nonetheless, in the respective Bremen mosque this sparked an intra-Muslim debate about the relationship of religion and politics, and more nuanced newspaper reporting on the diverse views held in Muslim communities and organizations on this crucial issue.

In sum, whether or not the aftermath of $9 /$ I I and heightened public attention to Muslim religious and political organizations in the US, Germany and beyond will eventually result in increased immersion or even incorporation of such groups in political life, is too early to say. It may suffice to draw the preliminary conclusion that on various sides the awareness to urgently include Muslim organizations in regular political and religious life has grown much stronger. Perhaps we see increased efforts of political gatekeepers to co-opt Muslim leaders; along the lines practiced for two decades by French authorities, which led to the establishment of a beur-geoisie.

We should also be careful about the impact of 9/I I on wider issues of immigrant integration, such as tolerance towards cultural pluralism. Muslims all over Europe and the USA have suffered increased hostility and physical attacks, especially in the first months after 9/I I. For example, in the stronghold of European multiculturalism, the United Kingdom alone, more than 300 assaults on Muslims were reported in the first three months after the terrorist attacks (Eurobarometer 200I). Similar observations can be made for other countries such as Germany, France, and the Netherlands. We would thus expect that public support for state accommodation of Muslims' religious practices would have decreased after $9 / \mathrm{I}$ I.

Yet, according to data there is some initial evidence that at least public attitudes towards Muslim religious practices have not changed dramatically after 9/I I (Fetzer \& Soper 2002): This preliminary evidence comes from a Roper survey on "Religion and the State" carried out in three European countries before 9/II in July 200I and after 9/I I in April of 2002. The countries included were the UK, France and Germany. One item aimed to measure toleration of Islamic religious practices. The questions asked were different in the three countries because state-religion relations and public debates around the integration of new religious beliefs have varied across these countries. The specific item concerned public support of Islamic religious practices pertaining to schools. In the UK, the question was: Should the state continue to fund Islamic schools? In Germany, it read: Should the state support Islamic religious instruction in public schools? In France, the question aimed at whether it should be tolerated or allowed to wear a headscarf. Interestingly, the empirical results only 
partially confirm the expectation that public support for state accommodation of Muslims' religious practices in the schools decreased. In all three countries, respondents were less likely after 9/I I to support the accommodation of Islam in state-run schools. However, in none of the three countries did the interviewees not become markedly anti-Islamic: their propensity to oppose accommodation only changed by a few percentage points in Britain and Germany; while the French result was statistically insignificant. This is noteworthy because most respondents probably knew from mass media reports that some of 9/I I terrorists lived in Germany and Britain. Overall, the respondents in the UK and Germany seem to be far more tolerant towards Islam than reports in the popular press might suggest.

We can only speculate about explanations for this result. Maybe we need to take a closer look at the realms in which immigrants can legitimately express cultural difference from majority groups. Historically, for example, the so-called 'ethnic groups' in the USA in the first half of the $20^{\text {th }}$ century could continue displaying cultural difference in the field of religion. This was not seen to contradict assimilationist goals (Herberg I955). Religious affiliation has been a legitimate way to express cultural difference. Such a finding should even be more applicable nowadays, as cultural pluralist tendencies have certainly gained increased acceptance over the past decades in the USA and Europe.

\section{Conclusion: Vicious and Virtuous Transnationalization}

The responses to 9/II and their consequences, such as a rise in meta-politics and discussions on the accommodation of Muslims in Western immigration countries, have profound implications for a research agenda on migration and security. So far, there is an imbalance in research on migration and security. Following public discourses, migration scholars have mostly either defensively argued against making a link between migration and terrorism or have pointed out substantial security threats for people and states emanating out of civil wars, refugee flows, and nationalist struggles involving categories such as militant refugee warriors (cf. the contributions to International Migration Review, No. I, 2003). Without denying the importance of such analyses, it is vital that they be complemented by two extensions. Obviously, the first task includes the rigorous study of the meta-politics of migration and security as part of migration politics. This does not only include the study of anti-immigrant violence but also the rhetoric of regular immigration politics and thus the securitization of migration and integration issues.

The second task is to extend our knowledge not only about the role of transnational processes in order to counter the easy linkage made between international migration and terrorism. This implies that we not only study the import 
viz. export of conflicts through international migration such as 'long-distance nationalism' (Benedict Anderson) but also more virtuous cycles of transnationalization such as the diffusion of human and civil rights with the help of émigrés, migrants and refugees. 9/I I has once again confirmed what has already been evident from less spectacular forms and manifestations of international terrorism: the growing importance of non-state actors in the contemporary world system (cf. Held et al. I999). This implies a study of political, economic and cultural transnationalization in all its facets. In this way we can hope to unearth both the vicious and the virtuous cycles of transnational processes.

This research emphasis would constitute one modest step towards removing fuzzy fantasies about the proverbial "stranger" and "migrant" as a security threat. This is important because, at first sight, the events of 9/I I have dealt another devastating blow to the Kantian utopia of perpetual peace. Yet, we need to be aware of the ambiguous dynamics of globalization. The age of globalization demands to renew Kant's vision. Immanuel Kant argued that perpetual peace is possible in a system of republics, which we would now call liberal democracies, governed by the rule of law (Kant I970). He wrote about a federation of states as one guaranty of peace. Nowadays this vision has to be supplemented by an empirical analysis of how transnationalizing civil societies may underpin the diffusion of human, civil and political rights. We thus should not only think about the ordering of the 'world of states' as a prerequisite for a more peaceful global order. Instead, we certainly need to include the 'world of societies'. Sometimes we then find ourselves indeed studying instances and vicious cycles of non-state violence crossing borders. This is important because there is a definite trend in our post-Westphalian political world, in which the sovereign powers of states are challenged and essential elements such as territoriality transformed without being replaced (Ruggie I993). International migration is one of the fields in which this can be exemplified. After all, international migrants actively voice ideas and interests in this transnational realm. This could act as a corrective to the current overemphasis on the migration-security nexus. In sum, in the world after 9/I I we need to search for a balanced way in studying vicious and virtuous cycles of transnational, non-state collective action and the ensuing responses by states and other governance structures. 
I Public Lecture held on May I 5, 2003 at the School of International Migration and Ethnic Relations (IMER), Malmö University.

2 Two of many examples are: Josef Joffe, "Das Weltgericht der Hundert Tage. Der I I. September, der Krieg gegen den Fanatismus und die Wiederentdeckung des Besten am Westen" (The World Judgement of Ioo Days: I I September, the War against Fanaticism and the Redisocovery of the Best in the West), Die Zeit, 27 December 200I, p.I, and "Der Glaube der Ungläubigen. Welche Werte hat der Westen?" (The Belief of the Non-Believers. Which Values has the West?), Der Spiegel 52, 200I, pp. 50-66.

\section{REFERENCES}

Allison, Graham (I97I), The Essence of Decision. Boston: Little Brown. Birg, Herwig (200I), Die demographische Zeitenwende. Der Bevölkerungsrückgang in Deutschland und Europa. Muenchen: C.H. Beck.

Buzan, Barry / Ole Waever / Jaap de Wilde (I998), Security: A New Framework for Analysis. Boulder, CO: Lynne Reinner.

Césari, Jocelyne (200I), Islam et l'extérieur, musulmans de l'intérieur: deux visions après le I I septembre 200I, Cultures et Conflit 44: 97-I I 5.

Coser, Lewis (1956), The Functions of Social Conflict. New York: Free Press.

Cottam, Martha (1994), Images and Intervention: U.S. Policies in Latin America. Pittsburgh: University of Pittsburgh Press.

Davies, Richard (2000), Neither here nor there? The Implications of Global Diasporas for (Inter)National Security, in: David T. Graham / Nana T. Poku (eds.), Migration, Globalisation and Human Security. London: Routledge, 23-46.

Eurobarometer (200I), Flash Eurobarometer I I 4: International Crisis. Released in December 200I, http://europa.eu.int/comm/public_opinion/flash/fl I I 4_en.pdf, accessed on I 4 July 2003

Faist, Thomas (I 994), How to Define a Foreigner? The Symbolic Politics of Immigration in German Partisan Discourse, 1978-1993, West European Politics I7, I: 50-7I.

Faist, Thomas (2000a), The Volume and Dynamics of International Migration and Transnational Social Spaces. Oxford: Oxford University Press. 
Faist, Thomas (ed.) (200ob), Transstaatliche Räume. Politik, Wirtschaft und Kultur in und zwischen Deutschland und der Türkei. Bielefeld: transcript.

Fetzer, Joel S. / J. Christopher Soper (2002), Public Attitudes toward European Muslims before and after September I I. Paper prepared for delivery at the 2002 Annual Meeting of the American Political Science Association, Boston, August 29-September I, 2002. http://apsaproceedings.cup.org/Site/abstracts/033/03300IFetzerJoel.htm, document accessed on July I4, 2003.

Fix, Michael / Jeffrey S. Passel, with María E. Enchautegui and Wendy Zimmermann (1994), Immigration and Immigrants: Setting the Record straight. Washington, D.C.: The Urban Institute.

Gibson, James L. (1998) A Sober Second Thought: An Experiment in Persuading Russians to Tolerate, American Journal of Political Science 42: 819850 .

Held, David/ Anthony McGrew/ David Goldblatt/ Jonathan Perraton (I999): Global Transformations: Politics, Economics and Culture. Stanford, CA: Stanford University Press.

Herberg, Will (1955), Protestant, Catholic, Jew: An Essay in American Religious Sociology. Chicago: University of Chicago Press.

Hirschman, Albert O. (1970), Exit, Voice, and Loyalty: Responses to Decline in Firms, Organizations, and States. Cambridge, MA: Harvard University Press.

Huntington, Samuel (1995), The Clash of Civilizations and the Remaking of World Order. Cambridge, MA: Harvard University Press.

IOM (International Organization of Migration) (200I), World Migration Report. Geneva: Bernan Associates.

Kant, Immanuel (I970), Perpetual Peace: A Philosophical Sketch, in: Political Writings, ed. By H.S. Reiss. Cambridge: Cambridge University Press (reprinted in 2000), 93-I30.

Keck, Margaret/ Sikkink, Kathryn (eds.) (1998), Activists Beyond Borders: Transnational Advocacy Networks in International Politics. Ithaca, NY: Cornell University Press.

Kepel, Gilles (1997), Allah in the West: Islamic Movements in America and Europe. Stanford, CA: Stanford University Press.

Kurth, James (I994), The Real Clash, The National Interest 37: 3-I 5.

Leonard, Karen (2003), Muslims in the U.S. New York: Russell Sage Foundation (forthcoming).

Lewis, Bernard (2003), The Crisis of Islam: Holy War and Unholy Terror. London: Modern Library.

Miller, Mark (2000), A Durable International Migration and Security Nexus: 
the Problem of the Islamic Periphery in Transatlantic Ties, in: David Grahm I Nana Poku (eds.), Redefining Security: International Migration and Global Security, London: Praeger, I 5-27.

Ruggie, John Gerard (1993), Territoriality and Beyond: Problematizing Modernity in International Relations, International Organization 47, 2: I39-I74.

Sales, S.M. / K.E. Friend (I973), Success and Failure as Determinants of Level of Authoritarianism. Behavioral Science I 8: I63-I72.

Saxton, Alexander (I97I), The indispensable Enemy: Labor and the anti-Chinese movement in California. Berkeley, CA: University of California Press.

Shain, Yossi (1989), The Frontier of Loyalty. Political Exiles in the Age of the Nation-State. Middletown, CT: Wesleyan University Press.

Sheffer, Gabriel (I993), Ethnic Diasporas: A Threat to Their Hosts? in: Myron Weiner (ed.), International Migration and Security. Boulder, CO: Westview Press, 263-285.

SOPEMI (I99I), Trends in International Migration. Paris: OECD.

Stern, Jessica (I999), The Ultimate Terrorists, Cambridge, MA: Harvard University Press.

Weiner, Myron (I995), International Migration and Security. Boulder, CO: Westview.

Zolberg, Aristide R. (1987), 'Wanted but Not Welcome': Alien Labor in Western Development, in: William Alonso (ed.), Population in an Interacting World. Cambridge, MA: Harvard University Press, 36-73. 


\section{ABOUT THE AUTHOR}

Thomas Faist is Professor of Political Science and directs the International Study Programme in Political Management at the University of Applied Sciences Bremen. He is director of the Center for Study of Migration, Citizenship and Development. His research focuses on International Migration, Ethnic Relations and Comparative Politics. Currently, he leads an international project on the Politics of Dual Citizenship in Europe, funded by the Volkswagen Foundation. He also participates in the Special Research Unit on "Changing Statehood", supported by the German Science Foundation.

Thomas Faist is member of the editorial boards of the journals Ethnic \& $R a$ cial Studies and The Sociological Quaterly. His major book publications include Social Citizenship for Whom? Young Mexican Americans in the United States and Turks in Germany (Ashgate 1995), The Volume and Dynamics of International Migration and Transnational Social Spaces (Oxford University Press 2000) and The Future of Citizenship (Blackwell, forthcoming).

Thomas Faist was Guest Professor in memory of Willy Brandt at IMER in Spring term 2003.

The Guest Professorship in memory of Willy Brandt is a gift to Malmö högskola financed by the City of Malmö, and sponsored by MKB Fastighets AB. It was established to strengthen and develop research in the field of international migration and ethnic relations, and to create close links to international research in this field. 


\section{Willy Brandt Series of Working Papers in International Migration and Ethnic Relations}

1/01 Rainer Bauböck. 2001.

Public Culture in Societies of Immigration.

2/01 Rainer Bauböck. 2001.

Multinational Federalism: Territorial or Cultural Autonomy?

3/01 Thomas Faist. 2001.

Dual Citizenship as Overlapping Membership.

4/01 John Rex. 2003.

The Basic Elements of a Systematic Theory of Ethnic Relations.

1/02 Jock Collins. 2003.

Ethnic Entrepreneurship in Australia.

2/02 Jock Collins. 2003.

Immigration and Immigrant Settlement in

Australia: Political Responses, Discourses and New Challenges.

3/02 Ellie Vasta. 2003.

Australia's Post-war Immigration - Institutional

and Social Science Research.

4/02 Ellie Vasta. 2004.

Communities and Social Capital.

1/03 Grete Brochmann. 2004.

The Current Traps of European Immigration Policies.

2/03 Grete Brochmann. 2004.

Welfare State, Integration and Legitimacy of the Majority:

The Case of Norway.

3/03 Thomas Faist. 2004.

Multiple Citizenship in a Globalising World: The Politics of

Dual Citizenship in Comparative Perspective.

4/03 Thomas Faist. 2004.

The Migration-Security Nexus. International Migration and Security before and after $9 / 11$ 
The Willy Brandt Series of Working Papers in International Migration and Ethnic Relations is published by the School of International Migration and Ethnic Relations (IMER), established in 1997 as a multi- and transdisciplinary academic education and research field at Malmö University.

The Working Paper Series is a forum for research in, and debate about, issues of migration, ethnicity and related topics. It is associated with IMER's guest professorship in memory of Willy Brandt. Thus, the Series makes available original manuscripts by IMER's visiting Willy Brandt professors.

The guest professorship in memory of Willy Brandt is a gift to Malmö University financed by the City of Malmö, and sponsored by MKB Fastighets $\mathrm{AB}$. The Willy Brandt professorship was established to strengthen and develop research in the field of international migration and ethnic relations, and to create close links to international research in this field.

The Willy Brandt Series of Working Papers in International Migration and Ethnic Relations is available in print and online.

\author{
MALMÖ UNIVERSITY \\ SE-205 06 Malmö \\ Sweden \\ tel: $+4640-6657000$ \\ www.mah.se
}

